\title{
Environmental Regulation Theory and Its Application
}

\author{
Li-ping WANG \\ School of Finance and Economics \\ Henan Polytechnic University \\ Jiaozuo, P.R.China \\ e-mail: lindsey18@hpu.edu.cn \\ www.hpu.edu.cn
}

\begin{abstract}
This article reviewed various arguments about environmental regulation and its theoretical basis, combined with the practice of environmental protection in China's enterprises, put forward several directions for further research, so as to provide a decision-making reference for the environmental protection work of China's enterprises.
\end{abstract}

Keywords-Environmental protection; Industry performance; Enterprise strategic response; Competitive advantage.

\section{INTRODUCTION}

With the continuous advance of environmental awareness, the idea of sustainable development involves into political, economic and social aspects, in this context, academics and politicians have repeatedly stressed the importance of economic security and environmental safety, relations of environmental issues and economy and trade have increasingly become prominent in the contemporary international politics and economy [1]. The international situation shows that developed countries taking the lead in making much stricter environmental regulation measures than developing countries is because of enormous environmental impact of production and usage, driving continuous policy innovation of global environmental regulation. The United Nations rapidly increased conventions, treaties and agreements of environmental protection since the "Conference on Human Environment" in Stockholm, 1972 enhancing international cooperation greatly. At the same time, consumers' awareness of environmental hazards of producing continued to improve, asking more about environment friendly products, with the appeal of environmental protection from international environment protect organizations, which show that enterprises will be faced with increasingly stringent environmental regulations under the multiple pressures from government, market, as well as international organizations.

\section{ENVIRONMENTAL REGULATION RESEARCH SUMMARY}

International academics mainly focus on the following three aspects about the need of environmental regulation [2-4]:

First, the view of environment protection and industrial performance. The implementation of environment protection would impact the cost at first, and then change the competitiveness of enterprises which would be reflected through industrial performance. Considering the relations between environment protection and industrial performance, there are two opposing views: (1) the conflict view of environment protection and industrial performance (Walley \& Whitehead), traditional environment economists generally believed that the requirements of Government implementing environment protections are to internalize environmental costs. In order to internalize, enterprises have to do extra payment for eliminating pollution and reducing environment damages, which will definitely increase the costs and heavy its burden. At the same time, environmental regulations from the government make enterprises have to transfer the limited funds from other investment projects so that it reduced the return on investment, in addition to mandatory of environment investment let enterprises must make changes in producing technologies and processes, which would also impede the normal technological innovation, resulting in decreased productivity. (2) The complementary view of environment protection and industrial performance. The most influential one is the win-win situation put forward by Michael - Porter and Linde (Porter, Linde). In their opinion, pollution is generated in the production process as a form of waste, inefficient use of resources, therefore, the design of an appropriate environmental policy that can guide enterprises looking for efficient methods using resources in order to reduce this waste, or looking for methods to turn waste into products with additional income, so that environment protection may reduce the cost or increase sales. And in addition, through first use of environment friendly technology enterprises would have first-mover advantage better than using traditional producing methods and technologies. Environment friendly products are possible for the enterprises having advantages of products' differentiation to better meet the needs of consumers with green consume demand.

Second, disputes of environment protection and trade. The impact of environmental regulation on the competitiveness of enterprises will bring the competitive position changes in international market; thereby affect a country's industrial competitiveness and even the competitiveness of the entire country, thus environmental problems changing into a country's trade policies to protect their own competitiveness. This dispute is further extended to the area of trade. On the coordination of the relationship between environment protection and competitiveness, developed countries believe that enterprises enjoying unfair competitive advantage in developing countries because of their lower environmental standards and no extra cost 
increase to meet environment needs, which calls for a variety of environmental trade measures to prevent developing countries doing environmental dumping with low standard products; Developing countries fear that too high environmental standards will make domestic enterprises lose price competitiveness in the international market, having doubts and misgivings on the implementation of stringent environmental protection standards. This shows that the impact of environmental regulation on the competitiveness of enterprises would go into the industrial and country-level competitiveness, and hence environmental issues controversy produced in the area of trade mainly related with the following opinions: (1) "Hypothesis of Competently Lower Standards". The theory (Bhagwati; Revesz) says that it is the free trade caused the lowering race in the global environmental standards. Treatment of the strength of environmental policies and enforcement of environmental standards of different countries or regions are similar to the occurrence of "The Tragedy of Public Place", that is, each country worrying about other countries lower the national environmental standards, which would cause a competitive disadvantage in this country's industries, so it will be competing for other countries in lower environmental standards in order to avoid the damage suffered by the competition. Every country will take sub-optimal environmental policy as if by prior agreement, finally resulting that environmental standards in every country are lower than that without the international economic competition, ultimately exacerbating the deterioration of global environment. What the theory described is totally different from the present circumstances because both the environmental standards have been improved to varying degrees both in developed and developing countries than in the past. (2) "Hypothesis of Pollution Haven", also known as industrial transfer hypothesis. The theory emphasized that (Cropper \& Oates) with the existence of free trade between countries, the implementation of environmental policies with low intensity and low environmental standards will enable enterprises pursuing profit maximization have greater advantages at the investment and production because of their internalization of external cost, attracting those enterprises in countries with high intensity of environmental policies and high environmental standards settle down in this country. Thus these enterprises subjected to relatively low environmental costs will have lower price than products in the home country. This "pull" due to the difference of internalization of environmental costs will be more strongly attractive for environmentally sensitive industries (enterprises) and those free enterprises. The current strength of environmental policy and environmental standards is in a lower level in developing countries, relatively speaking, developing countries, therefore, become polluter's "Paradise" and a "sanctuary" for the world's pollution-intensive industries inferred by this hypothesis. (3) "Eco-dumping". Developed countries think that developing countries enjoy the unfair cost advantage and competitive edge in the market because of different environmental standards in product costs causing their own at a competitive disadvantage. Taking these low-cost environmental standards as "Eco-dumping" they called for the harmonization of international environmental standards and requirements of eco-dumping duties levied by the Government or subsidy for their products, which in fact constitutes green barriers or environmental barriers. The so-called "eco-dumping" of the developed is just looking for an excuse for trade barriers. Tariff rates are declining and non-tariff barriers are removed, and the green barriers become the important mechanisms affecting the international trade development in 21 st century, gradually replacing the tariffs and general non-tariff barriers, which is an important means and higher form for trade protectionism of developed countries.

Third, resource-based perspectives impacting on the competitiveness. Wernerfelt, Dierickx \& Cool, Prahalad \& Hamel and others set up resource-based perspective according to the internal capability of enterprises, and pointed out that the competitive advantage is rooted in internal enterprise, depending on its valuable assets that can not be copied. Hart theorized the link between enterprise resources and natural environment, and emphasized the strategy capacities of three levels: pollution prevention, product liability, and sustainable development. Each of the strategies can be identified corresponding key resources and the caused competitive advantages, and these resources are unique. Pollution prevention, as opposed to the capital-intensive end treatment programs, requires their employees to participate, which is staff-intensive activity. Product liability is more complex, requiring integration of external stakeholders' opinion. Sustainable development asks enterprises set up a strong and shared opinion at all levels. When enterprises format complex environmental management capabilities, including silent-capability of whole quality management, complex social ability of cross-functional and cross-stakeholder management, scarcity capacity and sharing insight, the capabilities are not easy to imitate by other competitors, forming a sustainable competitive advantage.

Fourth, enterprise response strategy theory. Based on the competitive advantage, enterprises facing more and more stringent and complex environmental regulation strategies make different responses. The factors driving enterprises implementing different environmental strategies focus mainly on three aspects as follows: (1) System theory. System theory says that the external stress format action. This theory used to explain the relevance with strategy that enterprises pre-react to manage their environmental affairs. Results of empirical tests focus on the impact of compulsory stress on environmental activities, for example, Welch, Mazur, and Bretschneider think that regulation stress is the key factor to promote enterprises to participate in voluntary environmental programs of an industry; Hoffman's study shows that market control and the value-joint social factors affect environmental activities of enterprises, and points out at the same time that these pressures restrain economic activities in organization, but they also create an opportunity to form a competitive advantage for enterprises. (2) Stakeholder theory. The theory says that enterprises' environmental strategy reflects the preferences of multi-stakeholder. Freeman defined stakeholder as "any 
group or individual who is able to affect the realization of organizational goals or be affected by the achievement of organizational goals in turn". Stakeholders could express their interests and influence the practice of an organization through direct pressure or through the transmission of information. The environment literatures emphasize the four key groups: the control stakeholders, organization stakeholders, community stakeholders and the media. (3) View of enterprises' social responsibility proposes that enterprises are very sensitive to the obligation to bear on social responsibilities, so that their environmental behaviors are "morality". Carroll definite a three-dimensional concept model for the performance of enterprises, in which economic and legal obligation are the first level of responsibility, moral responsibility, behavior type and code of ethics belong to Level II, which are the expectations of society. Level III are free decided actions, 'leading by the enterprises' wish to play a role in participations in the community rather than mandatory or legal requirements, not with a moral significance to the expected commercial". At present, managers continually experience pressures from a number of stakeholder groups requesting resources on corporate social responsibility (CSR), including consumers, employees, suppliers, community groups, government, and some shareholders, especially institutional shareholders. Enterprises can build trust in the reputation by confirmation on ethical conduct in our sincere commitment, and form long-lasting, productive relationship, so that they gain a competitive advantage.

\section{CONCLUSIONS}

Environmental issues have gradually become the primary concern of all countries in the world, and have developed all kinds of environmental regulations and policy standards, at the same time, the concept of green consumption and environmental protection are increasingly popular, it can be seen that under the stress of government, market as well as multiple international organizations, enterprises will be faced with increasingly stringent environmental regulations. Against this background, the government and enterprises are not facing a matter of need environmental regulation or not anymore, but how to carry out environmental regulation, namely how to make the cost and benefit of environmental regulation achieve the Pareto optimal. Environment pollution is associated with industrialization and becoming serious with the advance of industrialization. China is no exception. Therefore, to actively explore the co-ordination model for China's economic growth and environmental protection under the benefits of sustainable development is extremely important and urgent. So the in-depth study of environmental protection issues in Chinese enterprises and the Government's environmental policy is a key issue to implement the mission of energy saving and emission reduction in our country.

\section{ACKNOWLEDGMENT}

This paper is supported by National Social Science Fund (No: 16BJY061).

\section{REFERENCES}

[1] $\mathrm{Li}$, Chuang. The main problems of China's environmental policy and countermeasures. Advanced Materials Research, v 997, p 804-807, 2014

[2] Zhao, Jinhua. Policy persistence in environmental regulation. Resource and Energy Economics, v 25, n 3, p 255-268, August 2003.

[3] $\mathrm{Li}$, Chuang. Research on enterprise environment sound technology innovation policy system. CECNet 2012 - Proceedings, p 512-514, 2012

[4] Liping, Wang. The inspiration of the economic restructuring in Ruhr of Germany to the sustainable development of mining cities in Henan province of China. Lecture Notes in Electrical Engineering, v 100 LNEE, VOL. 4, p 633-638, 2011. 